\title{
BETWEEN THE OLD METAPHYSICS AND THE NEW EMPIRICISM: COLLINGWOOD'S DEFENCE OF THE AUTONOMY OF PHILOSOPHY
}

\author{
Giuseppina D’Oro
}

\begin{abstract}
Collingwood has failed to make a significant impact in the history of twentieth century philosophy either because he has been dismissed as a dusty old idealist committed to the very metaphysics the analytical school was trying to leave behind, or because his later work has been interpreted as advocating the dissolution of philosophy into history. I argue that Collingwood's key philosophical works are a sustained attempt to defend the view that philosophy is an autonomous discipline with a distinctive domain of inquiry and that Collingwood's attempt to defend the autonomy of philosophy is intimately connected to his defence of intensional notions against the kind of meaning scepticism which came to prevail from the 1920s. I defend the philosophical claim that there is a third way between the idealist metaphysics with which Collingwood is often associated and the neoempiricist agenda which characterised analytic philosophy in mid-century by defending the hermeneutic thesis that Collingwood's work is a sustained attempt to articulate a conception of philosophy as an epistemologically first science. Since there is a via media between the old metaphysics and the new empiricism there is no need to choose between a certain kind of armchair metaphysics and a scientifically informed ontology.
\end{abstract}

The analytic tradition is often seen as arising out of the ashes of a form of Hegelian metaphysics that was revived by British idealists such as Bradley. ${ }^{1}$ It has become customary to read the history of the rise of analytic philosophy as the story of the gradual erosion of the a priori, a process which begun with Ayer's ${ }^{2}$ and the early Carnap's ${ }^{3}$ attack on metaphysics and culminated in Quine's ${ }^{4}$ dismissal of the analytic/synthetic distinction. ${ }^{5}$ This genetic story about how analytic philosophy originated does not necessarily tell us much about the essential character of analytic

\footnotetext{
${ }^{1}$ See Hutto, D. 'Foundations of Analytical Philosophy I: Early Analytical Philosophy', Philosophy Now, 8 (1993), pp. 14-18; Hylton, P., Russell, Idealism and the Emergence of Analytic Philosophy (Oxford: Clarendon Press, 1990) and Candlish, S., The Russell/Bradley Dispute and its Significance for twentieth-century Philosophy (Basingstoke and New York: Palgrave Macmillan, 2007).

2 Ayer, A. J., Language, Truth and Logic (London: Penguin Books, 1990; first published by Victor Gollancz, 1936).

${ }^{3}$ Carnap, R., 'Überwindung der Metaphysik durch logische Analyse der Sprache', Erkenntnis, 2 (1931), pp. 220-241; English translation: "The Elimination of Metaphysics Through Logical Analysis of Language" in A. J. Ayer, ed. Logical Positivism, Glencoe, Ill., The Free Press, pp. 60-81.

${ }^{4}$ Quine, W.V., 'Two Dogmas of Empiricism', The Philosophical Review, 60 (1951), pp. 2043.

${ }^{5}$ See Coffa, A., The Semantic Tradition from Kant to Carnap (Cambridge: Cambridge University Press, 1991) and Hanna, R. Kant and the Foundations of Analytic Philosophy (Oxford: Oxford University Press, 1991).
} 
philosophy today, if indeed there is any such character. From David Lewis to Jonathan Lowe, the latter half of the twentieth century has witnessed a return of substantive metaphysics that would be anathema to the earlier generation of analytic philosophers. ${ }^{6}$ Yet, with all the faults and imperfections that cling to grand narratives, the genetic story does nonetheless identify a certain philosophical trend in which the rise of the analytic tradition coincides with the increasing popularity of naturalism and the progressive erosion of a conception of philosophy as 'first science'.

How does Collingwood fit into the story of the rise of analytic philosophy? Not much has been written about Collingwood's intervention in the history of twentieth century philosophy, either because he has been dismissed as a dusty old idealist committed to the very metaphysics the analytical school was trying to leave behind, or because his later work has been interpreted as advocating the dissolution of philosophy into history.

This paper reassesses Collingwood's intervention in the history of twentieth century philosophy by taking a close look first, at the philosophical tête-à-tête with (the early) Ryle which took place in the aftermath of the publication of An Essay on Philosophical Method, ${ }^{7}$ and then at his attack on Ayer in An Essay on Metaphysics. ${ }^{8}$ I argue, firstly, that Collingwood's key philosophical works are a sustained attempt to defend the view that philosophy is an autonomous discipline with a distinctive method and subject matter and, secondly, that his attempt to defend the autonomy of philosophy is intimately connected to his defence of intensional notions against the kind of scepticism about meaning which came to prevail from the early 1920s and which found full expression in Quine. Collingwood saw the attempt to eliminate intensional notions along with traditional metaphysics as a case of throwing out the semantic baby together with the ontological bathwater. Both in An Essay on Philosophical Method and in An Essay on Metaphysics Collingwood was arguing

\footnotetext{
${ }^{6}$ Timothy Williamson has recently challenged this narrative in The Philosophy of Philosophy (Oxford: Blackwell, 2007), chapter 1. Williamson argues that a new narrative structure for the history of philosophy is needed because since the 1960s philosophy has witnessed "a revival of metaphysical theorizing, realist in spirit...", p. 19. Yet, Williamson himself may ultimately be said to belong to this narrative, at least to the extent that he denies philosophy has a distinctive method and autonomous subject matter.

${ }^{7}$ Collingwood, R.G. An Essay on Philosophical Method (Oxford: Clarendon Press, 1933). Revised edition with an introduction and new additional material, including the correspondence with Ryle, by Connelly, J. and D’Oro, G. (Oxford: Oxford University Press, 2005).

${ }^{8}$ Collingwood, R.G., An Essay on Metaphysics (Oxford: Clarendon Press, 1940). Revised edition, with an introduction by Rex Martin (Oxford: Oxford University Press, 1998).
} 
against that philosophical trend which, from the moderate empiricism of Ayer to the radical empiricism of Quine, is often identified with the narrative of the rise of analytic philosophy. That might well be the reason why, in spite of having made one of the most significant contributions to meta-philosophy in the twentieth century, Collingwood has not become part of the philosophical canon: his message was not sufficiently world-historical.

\section{The Essay on Philosophical Method and the correspondence with Ryle}

The correspondence between Collingwood and Ryle was prompted by an article in Mind ${ }^{9}$ where Ryle had presented a vitriolic critique of Collingwood's defence of the ontological argument in chapter IV of An Essay on Philosophical Method. Here Collingwood claims that the ontological proof applies in one case only, namely to the objects of philosophical thought or, as he puts it in a private letter to Ryle, to 'that which we are thinking about when we are thinking philosophically' ${ }^{10}$ Collingwood claims that when it is properly understood as applying to the objects of philosophical thought, the ontological proof will be viable, even if in a revised form:

My own view of the Ontological proof is that there is "something in it" as we say... but that its defect, in its traditional form, is that this something is often left vague, and that the term God (as anyone might indeed guess, who is familiar with the general drift of neo-Platonic and early medieval thought) has to be taken as standing for "that which we are thinking about when we are thinking philosophically". When this matter is made clear, it is to me also clear that the traditional ontological proof will have to be revised to bring it, so to speak, up to date; and this is what I have tried to do... ${ }^{11}$

In this revised form, the ontological proof applies not to God but to philosophical propositions, propositions which, according to Collingwood, define the domain of

\footnotetext{
${ }^{9}$ Ryle, G., 'Mr Collingwood and the Ontological Argument', Mind, 44 (1935), pp. 137-51.

${ }^{10}$ Collingwood's letter to Ryle dated 9 May 1935, in Collingwood, An Essay on

Philosophical Method, 2005, p. 257.

${ }^{11}$ Ibid.
} 
This is the pre peered reviewed version of the paper which will appear in Ratio XXV/1, March 2012. XXV(1) http://www.wiley.com/bw/journal.asp?ref=0034-0006

enquiry of first order sciences. 'Mind exists' and 'Matter exists' are paradigmatic examples.

But in what precise sense do the propositions 'Mind exists' and 'Matter exists' exemplify the structure of the ontological argument? Philosophical propositions may be said to exemplify the structure of the ontological proof because, like the proposition 'God exists', they are both a priori and ampliative. They are a priori because they can be known by reflecting on the explanatory practices of the firstorder sciences. They are ampliative (and therefore synthetic) because they make explicit something that is implicitly known by the practitioners of those sciences. The specific sense in which philosophical propositions are ampliative is captured by Collingwood's claim that philosophy

... does not, like exact or empirical science, bring us to know things of which we were simply ignorant, but brings us to know in a different way things which we already knew in some way... ${ }^{12}$

Because philosophical analysis makes explicit the conceptions of the real with which historians and natural scientists implicitly work, the results of philosophical enquiry can never be genuinely surprising for they are presupposed by the very conception of reality which they strive to clarify. But because philosophical knowledge engenders a certain kind of self-knowledge or self-understanding, philosophical propositions are not analytic in a narrow sense.

It is clear from Collingwood's conception of philosophical analysis that philosophical propositions like 'Mind exists' or 'Matter exists' do not exemplify the structure of the ontological argument if such an argument is meant to establish synthetic truths, where by synthetic one means extra-conceptual. Philosophical propositions are not ampliative in the sense that they predicate either mentality or materiality of some extra-linguistic entity which lies outside the domain of enquiry of the sciences of nature and mind. They are ampliative (and thus synthetic) only in the much more modest sense that they clarify what the domains of enquiry of different sciences are, what exists for the historian, and for the natural scientist. Whilst they

\footnotetext{
${ }^{12}$ Collingwood, R. G., An Essay on Philosophical Method, p. 161.
} 
may be called, as indeed Collingwood does on one occasion, 'synthetic a priori', 13 they are ultimately conceptual claims which clarify the conception of reality at work in the Geisteswissenschaften and Naturwissenschaften. For that is precisely what philosophical propositions are: second-order propositions which define the domain of enquiry of the first order disciplines.

Yet even in this revised form, Collingwood's attempted rehabilitation of the ontological argument failed to persuade Ryle who replied to Collingwood both in a number of private letters ${ }^{14}$ and publicly in a further article in Mind. ${ }^{15}$ In spite of Collingwood's clarification of the precise sense in which philosophical propositions may be said to exemplify the structure of the ontological argument, Ryle remained unsatisfied. There are, Ryle claims, only two kinds of propositions, propositions which are genuinely necessary and universal but are also merely hypothetical and have no existential import, and propositions which are contingent and have existential import, but which lack genuine universality. The former are what Hume referred to as propositions about relations of ideas, propositions such as 'all bachelors are unmarried men', and the latter are enumerative propositions about matters of fact, such as 'all men in the room are bachelors'. The proposition 'Mind exists' cannot be a relation of ideas, for it makes an existential claim and is thus not hypothetical. So if it is not an illicit metaphysical proposition, it must be rephrased as an enumerative proposition about matters of fact stating: ' $\mathrm{x} 1$ is minded, $\mathrm{x} 2$ is minded, $\mathrm{x} 3$ is minded etc'. Understood in this way, the proposition 'Mind exists' has existential import, but is also contingent rather than necessary. Ryle did not explicitly say so, but he could have said that the proposition 'Mind exists' is merely one amongst a series of 'systematically misleading expressions' in which the grammatical form of the proposition leads us to postulate the existence of an entity, in this case 'Mind', over and beyond the particulars or class of objects in which the concept is instantiated. ${ }^{16}$ Ryle's response is somewhat surprising because if for Collingwood philosophical propositions such as 'Mind exists' and 'Matter exists' are ampliative purely in the sense that they make explicit the conception of reality employed by historians and natural scientists, they are still at bottom analytic propositions which express

\footnotetext{
${ }^{13}$ Collingwood's letter to Ryle dated 6 June 1935, in Collingwood 2005, p. 318.

${ }^{14}$ Published in Collingwood, R.G., An Essay on Philosophical Method, 2005.

${ }^{15}$ Ryle, G., 'Back to the Ontological Argument', Mind, 46 (1937), pp. 53-57.

${ }^{16}$ See Ryle, G., 'Systematically Misleading Expressions', Proceedings of the Aristotelian Society, XXXII (1931-32).
} 
conceptual truths and which do not subvert the Humean fork. To say that 'Mind exists' is to say that historians are concerned with what exists qua actions or expression of thought and to say that 'Matter exists' is to say that natural scientists are concerned with what exists as events governed by causal laws. But if philosophical propositions are at bottom analytic propositions which do not make problematic extraconceptual claims, why did Ryle object to them?

The Collingwood-Ryle correspondence is illuminating precisely because it shows that Ryle's failure to understand Collingwood's defence of second-order, metalevel philosophical propositions, far from being just an expression of irritation towards anybody who dared even think of reintroducing talk of the ontological proof, was deeply rooted in a genuine disagreement about the nature of concepts. At the root of Ryle's disagreement with Collingwood's defence of philosophical propositions there lies a commitment to an extensionalist account of concepts that effectively prevents Ryle from acknowledging the possibility of a leaner, non-metaphysical notion of the synthetic a priori. For the sake of clarity I shall refer to the (metaphysical) notion of the synthetic a priori with which Ryle operates as synthetic a priori $_{1}$ and the (conceptual) notion with which Collingwood operates as synthetic $a$ priori $_{2}$. For Ryle a judgment is synthetic a priori $i_{1}$ if it is necessary, universal and has existential import. For Collingwood a judgment is synthetic a priori $2_{2}$ if it is a second order proposition which defines the domain of enquiry of the first order sciences. Like propositions concerning relations of ideas, propositions which define the domain of enquiry of different sciences are necessary and universal. From the perspective of the historian, all actions must be expressions of thought or mind because if something is not an expression of thought, then it could not (in virtue of what we mean) be an action. That 'actions are expressions of thought or mind' is thus not a contingent and enumerative proposition about matters of fact, but a necessary and universal proposition which captures the domain of enquiry of history or the conception of reality with which the historian operates. Synthetic a priori propositions 2 are also ampliative. But since, as we have seen, what makes philosophical propositions ampliative is not that they involve reference to an extra-conceptual element, but that they bring to light what we already implicitly know, philosophical propositions are ultimately analytic, even if not merely definitional. On the surface, the disagreement between Collingwood and Ryle is over whether there are synthetic a priori judgments ${ }_{1}$. Collingwood's defence of the ontological proof is what prompts Ryle's 
denial that there are any necessary existential judgements, including philosophical propositions such as 'Mind exists' and 'Matter exists'. On closer inspection, however, the disagreement is about whether there are synthetic a priori judgments ${ }_{2}$ and the bone of contention is not whether it is possible to make ontological claims from the philosophical armchair in the manner of classical rationalist metaphysics, but whether we are entitled to employ concepts, such as that of mind, which cannot be defined extensionally. Whilst Collingwood's attempt to defend the possibility of a third kind of proposition via the ontological proof suggests, as Ryle indeed assumed, that this third kind of proposition is both a priori necessary and has existential import, a careful reading of the philosophical context in which Collingwood's rehabilitation of the ontological proof is mounted shows that what drives Collingwood's defence of philosophical propositions is not an attempt to vindicate rationalist metaphysics by challenging the Humean fork, but an attempt to vindicate the right to use concepts which cannot be defined extensionally.

Collingwood's conception of the synthetic a priori is best understood in the context of his account of the overlap of classes, for it is here that he explains what it is that we are thinking about when are thinking philosophically or, in other words, what the objects of philosophical thought are to which the ontological proof is said to apply. In An Essay on Philosophical Method Collingwood claims that whilst the coordinate species of an empirical genus form mutually exclusive classes, the coordinate species of a philosophical genus may in principle allow for full extensional overlap, and that it is the task of philosophy to distinguish between concepts that coexist in their instances. ${ }^{17}$ Consider, for example, the empirical concept "colour" and its coordinate species "red" and "blue". If an object is red all over, it cannot be blue all over. Red and blue are thus mutually exclusive empirical classes. The same does not apply to the coordinate species of philosophical concepts. To illustrate this claim Collingwood considers a distinction often made by moral philosophers between the concept of duty and that of utility. This, Collingwood claims, is a distinction to which there correspond no well-defined empirical differences. The concept of duty and that of utility form overlapping empirical classes because an action performed for instrumental considerations could in principle also be performed for duty's sake. It is the task of the philosopher to make the purely intensional distinction between the

\footnotetext{
${ }^{17}$ See Collingwood, R.G., An Essay on Philosophical Method, p. 51.
} 
concept of duty and utility even when such concepts have mutually overlapping empirical classes and thus fail to 'cut nature at the joints'. The distinction between the concept of mind and matter, for Collingwood is analogous to the distinction between duty and utility. It is, in other words, a purely intensional distinction to which there correspond no well defined empirical classes and which is nonetheless required in order to avoid conceptual errors of the kind that would arise by conflating the criteria of identification for actions and events.

As the doctrine of the overlap of classes makes clear, Collingwood's defence of philosophical propositions is not motivated by a metaphysical agenda for his goal is not to advocate the existence of Mind and Matter as mind-independent metaphysical entities, but to drive a wedge between the extension and the intension of concepts. As he puts it in the correspondence:

I am disposed to think that what makes a number of things instances of a class is the common possession of some nature, and that this common nature (the so-called universal) is thus the ratio essendi of the class as such. Instead of resolving the theory of universals into the theory of classes, I should therefore be inclined to take the opposite line, of resolving the theory of classes into the theory of universals..."18

The concepts of Mind and Matter, according to Collingwood are 'transcendentals'. ${ }^{19}$ They are concepts that cannot be justified empirically because they determine the meaning of what it is to be. Whilst we may justify the employment of empirical concepts, such as those of crystalline or sedimentary rocks, by pointing to their instances, we cannot justify in a like manner the concepts of duty and utility, or the concepts of mind and matter, for the objects which fall under one of these concepts may also fall under the other. ${ }^{20}$ We can get a hold on such concepts, and the distinctions that they enable us to make, only if we acknowledge that the intension of concepts is not reducible to their extension and that a theory of concepts is not

\footnotetext{
${ }^{18}$ Collingwood's letter to Ryle dated 9 May 1935 in Collingwood 2005, p. 292.

${ }^{19}$ Collingwood refers to philosophical concepts as "transcendentals" in his methodological introduction to the 1929 "Lectures on Moral Philosophy". Unpublished. Deposited in the Bodleian library Oxford.

${ }^{20}$ Ibid
} 
reducible to a theory of classes. And this is precisely the bone of contention between Collingwood and (the early) Ryle.

Whilst Ryle accuses Collingwood of having been misled by the grammatical structure of the proposition into believing in the existence of metaphysical entities, Collingwood, for his part, believes that the extensionalist account of concepts to which Ryle is committed rests upon the fallacy of identified coincidents. ${ }^{21}$ Those who commit this fallacy erroneously assume that if two concepts coincide in their instances, then there is no distinction in the concepts themselves:

two concepts 'are the same thing' in the sense that a thing which exemplifies the one exemplifies the other also, but 'their being is not the same' in the sense that being an instance of the one is not the same as being an instance of the other. ${ }^{22}$

Collingwood's appeal to two senses of the term 'being' cannot be accused of violating Occam's razor for his point is not that Mind 'exists' in a special Platonic sense, but that there is a third way between metaphysics and empiricism, and that such a via media is revealed once one acknowledges the distinction between the intension and extension of concepts. So why did Ryle resolutely refuse to acknowledge the possibility of a third way? On the surface, it would appear that he rejected philosophical propositions as illicitly metaphysical because he identified synthetic $a$ priori judgments with judgments which are both necessary and existential. But this, as I have tried to suggest, cannot be the whole story since Ryle's repudiation of classical rationalist metaphysics only entails a rejection of the synthetic a priori in sense 1, not in sense 2. Thus Ryle's unwillingness to concede the possibility of philosophical propositions has as much to do with his identification of a theory of concepts with a theory of classes as it has to do with his rejection of classical metaphysics.

Ryle's extensionalist account of concepts attempts, in one fell swoop, to dispose both of the ontological claims made by classical metaphysicians and of the rather more modest conceptual claims advanced by Collingwood, according to which philosophical propositions, far from defining Mind or Matter into existence, delineate the domains of enquiry of the Naturwissenschaften and Geisteswissenschaften. Since

\footnotetext{
${ }^{21}$ Collingwood, R.G., An Essay on Philosophical Method, p. 49.

${ }^{22}$ Collingwood, R.G., An Essay on Philosophical Method, p. 50.
} 
This is the pre peered reviewed version of the paper which will appear in Ratio XXV/1, March 2012. XXV(1) http://www.wiley.com/bw/journal.asp?ref=0034-0006

Ryle does not acknowledge the possibility of a leaner, non-metaphysical interpretation of the synthetic a priori, he is not only unwilling, but also unable to accept Collingwood's view that there are second-order, meta-level propositions which define the distinctive domain of enquiry of philosophy.

\section{An Essay on Metaphysics and the verificationist principle of meaning.}

An Essay on Philosophical Method sought to carve out a distinctive domain of enquiry for philosophical analysis by defending intensional notions against the extensionalist stance endorsed by the early Ryle. Collingwood argued that there is a distinctive domain of enquiry for philosophy because philosophy is concerned with the propositions ('Mind exists', 'Matter exists') which express the conception of reality implicitly presupposed by first-order scientists. Yet though such propositions are not traditional metaphysical propositions making necessary existential claims in the manner of the ontological argument, they are nonetheless ruled out as illicit by identifying the theory of concepts with the theory of classes, if not by invoking the Humean fork. The extensionalist stance thus threatens not only the possibility of metaphysics, but also the very possibility of philosophy, understood as a second-order reflection on the first order sciences intent on disambiguating concepts which coexist in their instances. If philosophy is to be possible, as an epistemologically first science whose role is to define a priori the domain of enquiry of the first order disciplines, then there must be at least some concepts which do not cut nature at the joints and which elude Ryle's extensionalist treatment.

Although Collingwood never replied publicly to Ryle, not even to Ryle's second paper in Mind, he did pursue his defence of the autonomy of philosophy in a second treatise on meta-philosophy: An Essay on Metaphysics. Here he argued that the practitioners of different sciences make use of different senses of causation that reflect the distinctive nature of their explanandum. Historians are committed to what Collingwood refers to as sense I of the term 'cause'. As Collingwood puts it, in history 'that which is caused is the free and deliberate act of a conscious and responsible agent, and causing him to do it means affording him a motive for so doing. ${ }^{23}$ The word is used in this (historical) sense in expressions such as ' $\mathrm{Mr}$ Baldwin's speech compelled the speaker to adjourn the house' or 'a solicitor's letter

\footnotetext{
${ }^{23}$ Collingwood, R.G., An Essay on Metaphysics, p. 285.
} 
causes a man to pay his debt'. A historian's commitment to sense I of the term causation reflects the view that to explain actions means to make rational sense of them. Collingwood then considers the sense of causation employed in what he calls the practical sciences of nature, sciences such as medicine and engineering. In the practical sciences of nature the term cause is used in sense II to mean an antecedent condition that can be manipulated either to prevent or bring about a certain state of affairs. In sense II 'a cause is an event or state of things by producing or preventing which we can produce or prevent that whose cause it is said to be'. ${ }^{24}$ Thus, for a medical practitioner the bite of a mosquito would qualify as a possible cause (in sense II) of malaria, for the primary concern of the medical doctor is to prevent or cure diseases. Finally, the term cause may also be used (in sense III) in the theoretical sciences of nature to mean an 'event or state of things such that (a) if the cause happens or exists, the effect must happen or exist even if no further conditions are fulfilled (b) the effect cannot happen or exist unless the cause happens or exists. ${ }^{25}$ Sciences such physics, which abstract from human interests, employ the term 'cause' in this deterministic sense to indicate factors that are beyond human control. The different senses of causation at work in different explanatory practices are analytic for the practitioners of those practices because they spell out what it means to explain something as a particular of a certain kind, be it an action or an event.

It is precisely the attempt to defend the possibility of different senses of causation that leads Collingwood to take issue with the verificationist principle of meaning as defended in Ayer's Language, Truth and Logic. The verificationist principle, very much like Ryle's earlier condemnation of philosophical propositions as 'systematically misleading', threatens Collingwood's conception of philosophical analysis as a second-order enquiry which seeks to make explicit purely intensional distinctions, such as those holding between the different senses of causation that govern different explanatory practices. According to Ayer's verificationist principle propositions which are not empirically verifiable are meaningless (unless they are tautologies). The verificationist principle of meaning threatens the view that there are purely intensional distinctions between the different senses of causation that govern the explanatory practices of different sciences because the 'propositions' which unpack the conception of explanation at work in a given form of enquiry, propositions

\footnotetext{
${ }^{24}$ Collingwood, R.G., An Essay on Metaphysics, pp. 296-7.

${ }^{25}$ Collingwood, R.G., An Essay on Metaphysics, pp. 285-6.
} 
such as 'a cause is an event by producing or preventing which we can produce or prevent that whose effect it is said to be' are neither empirically verifiable nor are they tautologies.

An Essay on Metaphysics is Collingwood's second stab at the argument, already developed in An Essay on Philosophical Method, that philosophy has an autonomous domain of enquiry and that its distinctive subject matter are the categories or concepts which are presupposed by first-order scientists. Collingwood's line of defence against Ayer is that the 'propositions' which explicate the different conceptions of causation at work in different explanatory practices are not propositions in Ayer's sense, i.e. first-order empirical propositions. ${ }^{26}$ They are propositions of a higher order which express interesting (non-trivial) conceptual truths and supply the verification conditions at work in different explanatory contexts. Collingwood refers to these higher order propositions which express the meaning of causation at work in different explanatory contexts as absolute presuppositions and contrasts them to presuppositions that are merely relative. A presupposition is relative if it may be discarded without endangering the explanatory practice within which it is formulated. For example, the presupposition that 'the cause of malaria is the bite of a mosquito' is verifiable relative to the criterion of verifiability provided by sense II of causation and may be discarded without threatening the practice of medicine. A presupposition, by contrast, is absolute if it cannot be discarded without giving up the explanatory practice which it grounds. Thus, whilst doctors may incorrectly and yet consistently deny that there is a causal relation between smoking and lung cancer, they cannot consistently deny that 'the cause of an event is an antecedent condition by producing or preventing which we can produce or prevent that whose effect it is said to be' without giving up on medicine as a possible scientific enquiry. That 'the cause of an event is an antecedent condition by producing or preventing which we can produce or prevent that whose effect it is said to be' is analytic for medical practitioners.

The different senses of causation at work in the Geisteswissenschaften and the Naturwissenschaften commit their practitioners to the existence of different categories of things. For historians actions exist because historians explain what there is as an expression of thought. For natural scientists events exist because they explain what

\footnotetext{
${ }^{26}$ In An Essay on Metaphysics Collingwood uses the term "proposition" as short hand for "empirical proposition".
} 
occurs as an expression of causal laws. The vocabulary that Collingwood uses is markedly different from the one employed in An Essay on Philosophical Method, but the substance of what he says is the same: Actions and Events are categories not of revisionary, but of descriptive metaphysics that exist for the practitioners of the Geisteswissenschaften and Naturwissenschaften respectively, very much as Mind and Matter are meta-level concepts which exist for historians and natural scientists. The job of the philosopher is to distinguish these different categories by disentangling the different conceptions of causation that are absolutely presupposed in different explanatory contexts. Once again, Collingwood links the defence of a distinctive subject matter for philosophical analysis to his defence of intensional notions and our right to employ them beyond the context of merely tautological or narrowly analytical claims.

But, nota bene, to say that absolute presuppositions are non-empirical propositions which express interesting conceptual truths is not the same as saying that to deny, e.g. that 'there are actions' is to utter a contradiction in the way in which classical rationalist metaphysicians believed that to deny 'God exists' involves a contradiction. The contradiction arises only for the practitioner (historians, or natural scientists) who presupposes a certain conception of causation. There is no contradiction in claiming that 'there are no actions' as long as one does not seek to engage in the kind of explanatory practice which presupposes the intelligibility of the world of human action. The predicament in which the practitioners of a science find themselves is thus not dissimilar to the logician's predicament as described by Lewis Carroll in 'What the Tortoise said to Achilles' ${ }^{27}$. Carroll argued that the logician's ability to endorse the conclusion of any given deductive argument relies on the prior acceptance of a principle of valid inference which is implicitly appealed to when one infers from the premises to the conclusions and without which the inference would lack validity. Like the logician in Carroll's paper, first-order scientists are necessarily committed to principles of inference which determine the nature of their explanandum and which they are not at freedom to deny without changing the subject. ${ }^{28}$ Collingwood's criticism of Ayer, like his earlier criticism of Ryle, is that there are propositions which are true in virtue of meaning, and thus analytic in the broad sense,

\footnotetext{
${ }^{27}$ Carroll, L., 'What the Tortoise said to Achilles', Mind 4/1 (1895), pp. 278-280.

${ }^{28}$ For a discussion of Carroll see Hanna, R., Rationality and Logic (Cambridge: MIT Press, 2006), chapter 3.
} 
but which are not tautologous or analytic in the narrower sense accepted by logical positivism. So understood, Collingwood's claim that one should turn metaphysics into a study of absolute presuppositions implies not that metaphysics is an enquiry into what the practitioners of a science believe, but that absolute presuppositions express conceptual truths which cannot be discarded without overthrowing the very form of enquiry which they make possible.

The view that absolute presuppositions express interesting conceptual truths has substantive implications for the ways in which one understands the nature of Collingwood's intervention in the history of twentieth century philosophy. It is conventional wisdom to read Collingwood's An Essay on Metaphysics as advocating the dissolution of metaphysics into history by transforming metaphysics from an ontological enquiry concerning the ultimate structure of reality into a historical investigation concerning the beliefs that different people held in different periods of time. ${ }^{29}$ On this reading, Collingwood was not only trying to sever the link between metaphysics and ontology, he was also rejecting the view that there are propositions which are true in virtue of meaning alone. If, as the standard reading goes, metaphysics is an historical enquiry into the absolute presuppositions that people make at a certain time, then these presuppositions are true only for certain people at a certain time and are thus, in the last analysis, only more general propositions about matters of fact which do not differ in kind from first order propositions or what Collingwood called 'relative' presuppositions.

Wittingly or unwittingly the standard reading of Collingwood ascribes to him a conception of philosophy that is not incompatible with the naturalistic trend and the progressive attack on the $a$ priori that is sometimes identified with the narrative of the rise of analytic philosophy. For if there is no distinction in kind between philosophy and history, then there is no principled distinction between the domain of enquiry of philosophy and that of the first-order sciences, and Collingwood could not be seen as

\footnotetext{
${ }^{29}$ The view that the later Collingwood converted to historicism was first put forward by Malcom Knox in his introduction to the posthumously published The Idea of History and has subsequently been endorsed by commentators such as A. Donagan, The Later Philosophy of R. G. Collingwood (Oxford: Clarendon Press, 1962), N. Rotenstreich, 'Metaphysics and Historicism' in Critical Essays on the Philosophy of R. G. Collingwood, edited by M. Krausz (Oxford: Clarendon Press, 1972) and S. Toulmin in 'Conceptual Change and the Problem of Relativity' in Critical Essays on the Philosophy of R. G. Collingwood, edited by M. Krausz (Oxford: Clarendon Press, 1972).
} 
defending a view of philosophy as an autonomous discipline with a distinctive method and subject matter. His historicism would be a thinly disguised form of naturalism.

On the reading presented in this paper, Collingwood's work is best understood as resisting the philosophical trend which is often identified with the rise of analytic philosophy: the gradual erosion and ultimate elimination of the a priori and the related notion of analyticity. Whilst Collingwood did share with the newly emerging analytical tradition a critique of metaphysics understood as an ontological enquiry into the ultimate structure of reality, his criticism of metaphysics was not motivated by a desire to debunk either the epistemological distinction between empirical and $a$ priori propositions or the semantic distinction between analytic and synthetic propositions. On the contrary, his work is best read as a sustained attempt to defend intensional notions against the neo-empiricist agenda which came to dominate analytical philosophy in its early stages.

\section{Conclusion}

The Collingwood-Ryle exchange offers an interesting window onto the origins of analytic philosophy. It is interesting because Ryle misunderstands Collingwood's notion of philosophical propositions and because it shows that this misunderstanding, far from being superficial, springs from a commitment to an extensionalist account of concepts that ultimately makes it impossible to conceive of a leaner, nonmetaphysical notion of synthetic a priori judgments as expressing conceptual claims which define the domain of enquiry of first order disciplines and which are analytic for first order investigators. Ryle takes Collingwood's defence of the synthetic $a$ priori to amount to a defence of traditional metaphysics, but the fact that Ryle's criticism of Collingwood is based on a misunderstanding does not entail they agree on the way forward for philosophy. What emerges from the correspondence is that the disagreement between Ryle and Collingwood is fundamentally a disagreement about the role and character of philosophical analysis. Collingwood viewed the role of philosophical analysis as that of conceptually disentangling concepts that coincide in their instances, and thus ascribed an important role to philosophy in clarifying the domains of enquiry of different sciences. Ryle failed to grasp the precise nature of Collingwood's defence of the autonomy of philosophy, not only because he was unwilling to rehabilitate old-fashioned metaphysics (the ontological proof was, as I have tried to show, just a smokescreen for the real issues), but because he was 
This is the pre peered reviewed version of the paper which will appear in Ratio XXV/1, March 2012. XXV(1) http://www.wiley.com/bw/journal.asp?ref=0034-0006

committed to an extensionalist account of concepts that barred him from acknowledging the possibility of purely intensional distinctions between the domain of enquiries of different sciences.

An Essay on Metaphysics revisited the same themes of An Essay on Philosophical Method and sought to articulate a defence of the autonomy of philosophy in a language that would have been familiar to the readers of Ayer's Language Truth and Logic. But it has been widely misunderstood as providing an argument for the dissolution of philosophy into history. On the conventional reading of An Essay on Metaphysics, Collingwood sought to dissolve metaphysics into history by transforming it from an enquiry into what there is or exists into an enquiry into what different groups of people have believed in different moments of time.

Metaphysics is effectively replaced by group psychology or cultural anthropology. As a result, whilst Collingwood's first meta-philosophical treatise has been attacked for harking back to a pre-Humean notion of metaphysics, his second meta-philosophical treatise has been erroneously accused of being insufficiently philosophical. As I have tried to argue, Collingwood was seeking neither to rehabilitate classical rationalist metaphysics, as the early Ryle argued, nor to turn philosophy into cultural anthropology, as the standard reading of An Essay on Metaphysics claims. In both cases he was seeking to delineate a distinctive domain of enquiry for philosophy by carving out a via media between the old metaphysics and new empiricism. This approach involved challenging the narrow conception of analyticity admitted by Ayer and defending the possibility of interesting conceptual truths. Unfortunately, Collingwood's defence of the autonomy of philosophy was caught between the proponents of two powerful historical trends, one in decline, the other in the ascent. Squeezed, both logically and historically speaking, between two currents that allowed for no third way, his defence of the autonomy of philosophy was hardly understood. As a result, An Essay on Philosophical Method and An Essay on Metaphysics have failed to be recognised for what they arguably are: the two most sustained attempts to carve out a distinctive domain of enquiry for philosophical analysis and to defend the autonomy of philosophy in the twentieth century.

Keele University, School of Politics, International Relations and Philosophy, Staffordshire, ST5 5BG, UK. Email: g.d'oro@keele.ac.uk 
This is the pre peered reviewed version of the paper which will appear in Ratio XXV/1, March 2012. XXV(1) http://www.wiley.com/bw/journal.asp?ref=0034-0006 